Article

\title{
Social Sustainability Dilemma: Escape or Communicate? Managing Social Risks Upstream of the Bioenergy Supply Chain
}

\author{
Elena Fedorova $^{1, *}$, Kirsi Aaltonen ${ }^{2}$ and Eva Pongrácz ${ }^{1}[$ \\ 1 Faculty of Technology Energy and Environmental Engineering Research Unit, University of Oulu, \\ P.O. Box 4300, 90014 Oulu, Finland; Eva.Pongracz@oulu.fi \\ 2 Faculty of Industrial Engineering and Management, University of Oulu, P.O. Box 4300, 90014 Oulu, Finland; \\ Kirsi.Aaltonen@oulu.fi \\ * Correspondence: elena.fedorova@oulu.fi
}

Received: 3 December 2019; Accepted: 7 January 2020; Published: 15 January 2020

check for updates

\begin{abstract}
Supply chain risk management has been well researched over the years. However, management of social risks in bioenergy supply chains has been studied less in contemporary research. The ability of bioenergy companies to identify, properly address, and communicate social sustainability has become crucial for many global producers. In order to meet current EU's energy and climate targets, the development of sustainable bioenergy production is vital. However, over last decade, research of bioenergy production supply chains has indicated that upstream areas of global bioenergy production systems are vulnerable in terms of social sustainability risks. The main objective of this research was to demonstrate how the socially sustainable supply chain practices in bioenergy supply chains can help a production company manage social risks and resources-use related conflicts upstream of the supply chain. These practices can be applied in the process of negotiation between bioenergy producers, local authorities, and communities for creating win-win situations for all parties while planning new bioenergy production systems. This study pays special attention to social sustainability risks at the upstream of the supply chain in countries of raw material origin. Use of social sustainability practices intends to help identify, assess, and address social risks of supply chain activities for bioenergy companies. Moreover, such practices aim at supporting companies and their stakeholders in making right choices and preparing effective strategies ahead of time. We based our research on empirical evidence and offer solutions to multi-national bioenergy production companies on how to manage social risks, allowing them to make the right decisions and necessary adjustments before entering potential markets. Our findings show that even avoidance of market entrance can carry sustainability-related social risks for both the company and the local communities. We suggest that although the financial element plays an important role in decision-making, the no-go decision often means missed opportunities for local communities to improve their respective sustainability states.
\end{abstract}

Keywords: socially sustainable supply chain; use of resources and social risks; bioenergy supply chains; upstream; stakeholder involvement

\section{Introduction}

The European strategy for building a sustainable, bio-based economy stresses the importance of following the revised Renewable Energy Directives (RED II) rules in order to achieve its $32 \%$ renewable targets by 2030 [1].

RED II directive published in 2018 introduces the new approach that reinforces the sustainability criteria of bioenergy through different provisions, especially concerning high Indirect Land-Use 
Change (ILUC) risk biofuels. It sets limitations for those biofuels' production, with the suggestion to move toward production of certifiably low ILUC-risk biofuels, bioliquids, and biomass fuels. Such requirements push major EU bioenergy production to move their feedstock production into new developing markets. The RED II directive sets out sustainability criteria for all bioenergy-based fuels produced and consumed in the EU to make sure that they are produced in a sustainable and environmentally-friendly way [2]. However, social sustainability criteria in the directive are still limited. They mostly concern job creation [1]. The complex approach of overseeing and preventing raising problems of social sustainability in the countries of biomass origin is not specified in RED II directives. Tools and guidelines on how to deal with social issues companies do not have direct control over are not available to EU companies.

When it comes to sustainability assessments of feedstock used for biofuel production, there are still many grey areas that are difficult to oversee or improve for many EU bioenergy production companies that operate on the global market. European multi-national bioenergy production companies, while expanding their operations to developing markets, often have to face many non-standard situations that may trigger the development of social sustainability issues, risks, and uncertainties. In its assessment on the impact of biofuels production on developing countries, the European Commission highlighted the lack of research, linking the production of conventional biofuels from diverse feedstock in The African, Caribbean, and Pacific Group of States (ACP) countries with corporate social responsibility instruments [3]. While there is a voluntary instrument, the Global Compact of United Nations-aiming to align business operations with ten universally accepted principles, the core areas of human rights, labour rights, environment and anticorruption-it lacks a conflict resolution instrument [4]. Even though there are general mechanisms and voluntary schemes available to ensure social sustainability compliance in the bioenergy sector, it is difficult for companies to choose the right tools and make the most optimal decisions when entering new markets.

Many conflicts related to bioenergy supply chain production, especially in countries of feedstock origin, have been detected over last two decades. Many research projects and specific programs have been developed to monitor and tackle those conflicts [5]. Issues of resources usage and human rights conflicts are the most alarming and make the bioenergy sector very vulnerable, requiring the special adaptation of existing sustainability criteria standards and tools.

Reducing costs and improving competitiveness are the main factors pushing bioenergy production companies to extend their supply chains to international markets. In view of the limited sizes of domestic markets, companies cannot get maximum benefits only using domestic resources. However, longer supply chains carry more risks for production companies.

Traditionally, companies considered risk management only in terms of economics, estimating only risks of potential monetary loses. Moreover, the overall structure of risk management is often presented as a compliance issue [6]. However, when it comes to sustainability management of entire production systems, the company's goals and objectives have to cover all three pillars of sustainability: economic, environmental, and social. Recently, the concept of sustainability-related risks in supply chains has been introduced [7]. Studies show that timely monitoring for social, environmental, and economic factors and issues along supply chains has a direct impact on stakeholders and is a condition for the successful management of supply chain risks. Incorporation of sustainability into risk management practices helps protect organizational image and increase shareholder value [7-9].

Over last decade, many researchers have dedicated their work to the importance of adoption of environmental sustainability practices, yet just few concentrate on socially sustainable chain practices [10]. The concept of the "green supply chain" has been studied and well represented in literature. The number of journals that are devoted to the environmental dimension of global supply chains is much higher than that devoted to the social dimension [10,11].

In the field of operational management, supply chain-related literature's focus has been primarily on environmental issues and just touching basic social aspects narrowed to health and safety issues and compliance with labour standards [12]. Only in recent years, the importance of managing diverse 
social and societal issues in the supply chains was taken to the level of broader theoretical and empirical understanding through abstraction and means of creating new much deeper knowledge about socially sustainable supply chains [13,14].

The social dimension of sustainability concerns the impacts an organization has on the social systems within which it operates. It represents corporate responsibility toward employees, society, business partners, and customers; that is why social sustainability risks have direct impacts on societal values, influencing social stability and personal well-being. Previous research indicated that risks related to social sustainability were perceived as "less risky" in comparison to environmental or economic risks. However, the same research states that issues related to social risks create high media exposure and may trigger bigger problems in the supply chain, such as boycotts of the company's products and legal cases on social injustice [15]. In our research, we identify and assess critical social risks related to sustainability of upstream bioenergy supply chain. Communicating and managing social sustainability risks is an ever more complicated process. Risks are not always tangible or quantifiable but, if not taken care of properly, they may produce heavy financial losses and damage to companies' reputations. Keeping the social sustainability of renewable energy systems at the high level requires an effective tool to manage undesirable social risks and impacts. That is why the assessment of social impacts has been studied as the subject of managing the social issues of development and production processes [16]. In the context of renewable energy systems, social risks have their own unique features and recognition. The specifics of activities of renewable energy supply chains have strong engagements with community involvement and well-being, raising the bar of evaluation to a higher level.

The EU regulatory framework for renewable energy production increases the demand for new research and for development of new techniques that will allow companies to understand the role of social resources and capital in the process of sustaining community and to manage social risks along the entire process of production The Initiative on Corporate Sustainability Reporting (CSR) emphasizes the importance of social sustainability assessment and reporting. Moreover, since 2018, companies with more than 500 employees are now to perform CSR on an annual basis [17]. An increasing number of bioenergy producers are also following recommendations of the Global Reporting Initiative [18]. There is also an on-going development in extending Corporate Social Responsibility principles to the entire supply chain [19]. Non-financial issues reporting is emerging, although there is still a lack of reliable tools or guidance to be used, especially for developing markets.

Responsible supply chain management (RSCM) practices are used by modern corporations for building positive reputations and avoiding supply chain operation interruptions. At the same time, failure to manage supply chains in a socially responsible manner may ruin corporate reputations very fast. Negative media publications and consumer boycotts are the biggest risks that companies may face if issues of social sustainability come up [20].

Social responsibility includes ethical behaviour, gender justice, the payment of a living wage, the use of appropriate labour, and labour relations. Ethical behaviour encompasses many activities, from reliable financial statements to abstain from pricing of any form of prohibition of bribery. Gender equality concerns equal treatment of men and women in the workplace, in terms of equal pay and equal promotion of opportunities. No matter where the organization operates, it is responsible for providing workers with decent wages. Use of appropriate labour through suppliers who do not use child or forced labour (do not operate sweatshops) is a constant problem in the clothing industry. Fair labour relations will include freedom of assembly for workers, freedom of association, and minimization of competitive relations with trade unions. Social responsibility, including ethics, is the foundation value for many organizations. Ethical violation of social responsibility puts firms at significant risk.

Recently, bioenergy energy production supply chains started to get more attention as an important element of supply chain performance assessment and perception by stakeholders, business managers, and the public [21,22]. 
To identify the social risks of bioenergy systems and deal with them correspondingly, companies need to establish an effective management system. Supply chain risk management (SCRM) has been widely used for assessment and separation of risks in a way such they can be managed with minimal losses [23]. The main activities of SCRM involve four sequential steps: risk identification, categorization, assessment, and response or mitigation. These steps can also be used for the evaluation of sustainability risks in the upstream of bioenergy production supply chains.

The concept of the socially sustainable supply chain (SSSC) has been derived recently. It is based on SCRM and addressing pressing social issues that global supply chains are facing today. SSSC practices are used to evaluate the benefits of social sustainability orientation in supply chains, examining the use of basic and advanced SSSC practices and what role they have for long-term operational performance Use of advanced SSSC practices that involve significant tailoring of processes and practices design has been proven to demonstrate strong influences on companies' images and operational processes, and increase values from stakeholder relationships to decrease social risks [24].

The academic literature shows broader perspectives on supply chain risk management than just economic loses or changes. Risk management and sustainability are evaluated together, and risk is understood as any issue with a wide effect that can prevent company from achieving specific targets [23]. However, the conceptualisation of social risks management is limited, and most corporations focus their attention on minimizing financial risks [25]. At the moment, there is a lack of research that studies social sustainability practices in relation to social risks.

Research question of our present study is: how can bioenergy production companies manage social sustainability risks upstream of their supply chains?

We stress the importance of developing social sustainability practices that will offer sustainability guidelines for companies, allowing them to make the right decisions at the right times.

Currently, there is a shortage of efficient tools and frameworks for social sustainability assessment on newly developing markets for multi-national companies. That is why in this article we introduce a social risk management decision-making tool that, in combination with the socially sustainable supply chain practices approach, can be utilized by bioenergy companies to decide on action, especially in situations they have no control over. We will show that communication with national/regional stakeholders and bringing benefits to local communities are keys to success.

The objective is also to demonstrate that "going above and beyond" the basic standards allows companies to develop their own unique set of efficient social sustainability supply chain practices and create positive benefits for all players involved in bioenergy production supply chains.

\section{Bioenergy Supply Chain Social Sustainability Risks}

The chain of supply for a biofuel is very complex and consists of raw material producers, logistics companies, storage and pre-processing stations, and end users. Biofuel supply chain management should provide three basic levels of management solutions to ensure the supply of finished products from source to destination in an effective and efficient manner. They are strategic, tactical, and operational. Many risks exist in bioenergy supply chains. For example, raw material-related risks are security of supply and price, demand for finished products, and price uncertainty. There are also risks before processing; production and yield risks; risks in transportation; and many others. These types of risks have been studied extensively in the academic literature [26,27].

An extensive study has been performed on the nature of general risks in the supply cha $[28,29]$. The most well-known supply chain risks are associated with supply disruptions caused by quality problems, liquidity problems, transportation delays, natural disasters, product design changes, stock market falls, or changes in the exchange rate $[30,31]$. These risks are typical and are usually classified into classes such as supply risks, procurement risks, relation risks, logistic risks, demand risks, etc. Typical risks can be also divided into two main categories: endogenous or internal risks along the supply chain caused by the companies' activities, and exogenous risks or external that come from outside players of the supply chain [23,32]. 
New risks that recently attracted attention are sustainability related risks [8]. They are connected to the triple dimensional view of sustainability where risks involve environmental, social, and economic areas of human life. Those risks are different from typical risks in many ways. They are connected to consequences regarding corporate reputation, conflicts with the law, and financial issues, rather than just to supply chain operations. Environmental risks are related to requirements towards the quality of a shared ecosystems where supply chain activities take place, such as sustainable use of available resources. The social dimension refers to the delivery of responsibilities towards employees, customers, business partners, governments, and societies along the supply line. They are more societal well-being related risks [33]. The financial dimension shows monetary risks created by the financial environment and may involve dishonest financial activities by companies and individuals, influencing economic growth in negative way.

Risk management of the supply chain, as a rule, is subject to risks arising from the continuity of materials flow, business process information, and monetary funds in the supply chain. For years, supply chain risk management has generally been defined as the potential influence of events that may have significant detrimental impacts on a company's purchasing power. While supply chain risks and sustainability issues seem to be important elements for supply chain managers today, they are often viewed in isolation $[33,34]$.

In recent years, issues of social sustainability risks in bioenergy supply chain identified the set of interlocking challenges [35]. However, from a real-world perspective, social sustainability risks in bioenergy supply chains are not visible; that is why stakeholders such as the media, non-governmental organizations (NGOs), and public agencies are trying to attract attention to the issues of social sustainability. Often, lack of understanding of how social sustainability issues in the supply chain materializing as a risk in the long-term impose a potential threat reputation loss. By raising social sustainability standards along the supply chains of companies, one may reduce the number of risks $[7,35]$.

Production outsourcing can produce economic benefits to a company; at the same it may carry hidden social risks in the upstream of the supply chain. Thus, the high level of value creation in the upstream of supply chains, increasingly stringent regulations, CSR reporting requirements, and pressure from stakeholders regarding compliance with social issues, contribute significantly to rising attention to social risks from corporate and academic communities [36]. Misconduct of fair social practices may lead to bad publicity and later to the loss of reputation for a company. Especially for large companies, being responsible for handling risks in the upstream supply chain plays an important role in the process of building global reputation [7,37].

Managing social risks in the supply chain has become extremely challenging, as more and more companies have moved feedstock production to overseas locations, supply chains have been extended, the number of nodes have increased, and the complexities of the networks have moved exponentially. The geography of countries originating raw bioenergy materials is very diverse and often unknown to the end user of the supply chain.

The social risks' sensitivity to a bioenergy production supply chain upstream is very high. The number of bioenergy production corporations is growing, as is the number of cases related to socially suitable practices, both positive and negative, that appear in the media and academic literature.

Taking into account decentralization issues of bioenergy supply chains, it is essential to maintain a dialog with stakeholders in order to define the target criteria of this process. The bioenergy production industry requires multi-stakeholder approach, which guarantees that the different concerns, especially concerns directly affected by policy decisions, are heard and taken into account [38,39]. Stakeholders' dialogue helps to balance between economic development, environmental issues, and social concerns [40]. An effective social risk communication model provides stakeholders with practical information about social risks in the supply chain, builds trust and credibility between involved parties, spreads awareness on levels of concern, helps to respond to acute situations, maintains positive images, and keeps public trust. 
The evidence on the research related to social sustainability risks management in bioenergy production upstream of the supply chain is not well defined and is often evaluated as part of part of environmental and economic sustainability risks [41,42]. Competently built relations with stakeholders using two-way communication can became an effective tool that can improve the accuracy of risk assessment. In combination with more traditional forms of risk assessment, stakeholder participation can play the role of a core factor and can help supply chain managers and investors more adequately assess social risks and benefits associated with a decision on new bioenergy production developments. It is important to develop transparent participatory processes and models embedding active engagement of stakeholders, establishing social sustainability standards, following obligations to improve human well-being in the areas of bioenergy production, and emplacing long-term sustainability plans that will improve the social sustainability of the bioenergy sector.

\section{Socially Sustainable Supply Chain Practices}

The practice of addressing social issues in modern bioenergy supply chains may create a number of benefits and challenges for a company. It can help to build a good image and bring positive benefits to communities. At the same time, due to the complexity of bioenergy production chains and lack of knowledge, there are dilemmas as to what practices to choose and how to maximize the positive effects of these practices on company's operations.

There are a number of socially sustainable supply chain (SSSC) practices that are currently considered as critical by most global bioenergy producers. Human rights protection, eliminating child labour, occupational and communities' health and safety, and maintaining working conditions are the most critical to watch out for and manage [43-45]. The challenges of corporate social sustainability practices' adoption in the upstream areas of bioenergy production create an external pressure on decision-making process [24].

Depending on the nature of operations and geographical location, SSSC practices may have different impacts on business operations. Supplier sustainability behaviour and performance as well as infrastructural and societal level of development in the country of raw material production have a direct influence on the selection of SSSC practices [46]. However, most researchers suggest companies should limit their social sustainability practices to the extent of just few key issues and monitor only key upstream suppliers [36,47]. On the other hand, the integration of socially sustainable practices and supply chain management is currently discussed in much wider range of SSSC practices implementation. Multiple entities across supply chains create additional social accountabilities that have to be taken into consideration. Only by fulfilling societal responsibilities in an efficient way and through establishing best practices and mechanisms to pursue their sustainability goal, can companies improve the sustainability performance of their supply chain $[48,49]$.

Based on sustainable supply chain management (SSCM) literature and studying aspects of social sustainability, two groups of SSSC practices have been identified: basic and advanced. Basic SSSC practices are concerned only with processes and procedures that are already well-established and required by law. Such practices are usually related to occupational health and safety, basic training, and monitoring management systems [50].

Advanced SSSC practices go beyond such limitations; they are more flexible, open to new processes, involve communication with diverse stakeholder groups, and endorse transparency of social sustainability information flow. Implementation of advanced SSSC practices requires a readiness to change from current operations and processes, in order to study and adopt practices that will socially benefit markets and communities they intend to enter [24].

Current trends show that companies are starting to pay much more attention to social sustainability issues in their supply chains. GRI's reporting guidelines provide tools for companies to make their social sustainability performance transparent. Socially sustainable management actions can be derived from GRI guidelines and embedded into companies' practices. GRI provides companies with guidelines that may help manage supply chain social sustainability risks; however, a bioenergy production 
company should map and build its own flexible set of social sustainability supply chain practices that can be modified based market specifics. With the diverse strategies of company activities and policies, stakeholder involvement allows them to build "social sustainability culture" that makes the decision-making process socially sustainable [50].

New recommendations developed by GRI in 2017 suggest that sustainability reports should include information that reflects where the most significant sustainability impacts happen, whether in the company or elsewhere up its value chain. The GRI suggests that all types of impacts are to be shown: positive and negative; short term or long term; direct or indirect; and even actual or potential. Such an approach allows companies to define critical points and pinpoint locations for change either in the management approach or in the process flow.

About $92 \%$ of 250 of the world's largest corporations nowadays report their social sustainability performance on annual basis. $74 \%$ of these use GRI's suggested standards for assessment and reporting. With continues updates and adaptations, since 2014 and until today, the Global Sustainability Standards Board was able to build the detailed Sustainability Reporting Standard Guidelines that are based on a multi-stakeholder approach and represent a combination of technical expertise and diversity of experience to address the needs of all report makers and users [18]. Social sustainability standards are covered in detail and are often suggested to be evaluated based on industry specifics.

Table 1 represents the allocation of GRI guidelines based social sustainability indicators along a bioenergy production supply chain based on the most important to relations to social risk management. The question marks indicate of uncertainty of whether issues related to a particular indicator may arise at this stage.

Table 1. Social sustainability indicators along a bioenergy production supply chain.

\begin{tabular}{|c|c|c|c|c|c|}
\hline \multirow[b]{2}{*}{$\begin{array}{l}\text { Supply chain } \\
\text { stages: }\end{array}$} & \multicolumn{2}{|c|}{ Upstream } & \multirow[t]{2}{*}{ Midstream } & \multicolumn{2}{|c|}{ Downstream } \\
\hline & Feedstock & ogisti & & Distribution & $\begin{array}{c}\text { Product } \\
\text { Use }\end{array}$ \\
\hline \multicolumn{6}{|l|}{ GRI Social indicators } \\
\hline 401 Employment & $\checkmark$ & $\checkmark$ & $\checkmark$ & $\checkmark$ & \\
\hline 402 Labour & $\checkmark$ & $\checkmark$ & $\checkmark$ & $\checkmark$ & \\
\hline 403 OHS & $\checkmark$ & $\checkmark$ & $\checkmark$ & $\checkmark$ & \\
\hline 404 Training & $\checkmark$ & $\checkmark$ & $\checkmark$ & $\checkmark$ & \\
\hline 405 Equality & $\checkmark$ & $\checkmark$ & $\checkmark$ & $\checkmark$ & \\
\hline 406 Non-discrimination & $\checkmark$ & $\checkmark$ & $\checkmark$ & $\checkmark$ & \\
\hline 407 Collective bargain & $\checkmark$ & $\checkmark$ & $\checkmark$ & $\checkmark$ & \\
\hline 408 Child labour & $\checkmark$ & $?$ & & & \\
\hline 409 Forced labour & $\checkmark$ & $?$ & & & \\
\hline 410 Security & $\checkmark$ & $\checkmark$ & $\checkmark$ & $\checkmark$ & \\
\hline 411 Indigenous & $\checkmark$ & $?$ & & & \\
\hline 412 Human rights & $\checkmark$ & $?$ & & & $\checkmark$ \\
\hline 413 Local communities & $\checkmark$ & $\checkmark$ & & & \\
\hline 414 Suppliers & $\checkmark$ & $\checkmark$ & & & \\
\hline 415 Public policy & $\checkmark$ & $\checkmark$ & $\checkmark$ & & \\
\hline 416 Customer health & & & & & $\checkmark$ \\
\hline 417 Marketing & & & & $\checkmark$ & $\checkmark$ \\
\hline 418 Customer privacy & & & & $\checkmark$ & $\checkmark$ \\
\hline \multicolumn{6}{|l|}{ RESOURCE USE } \\
\hline 413-2 Access to land & $\checkmark$ & & & & \\
\hline 303-1 Water access & $\checkmark$ & & & & \\
\hline 304-2 Biodiversity & $\checkmark$ & & & & \\
\hline
\end{tabular}

\section{Empirical Illustration of Resource-Use Conflicts and Resolution}

Sustainable production is the top priority for the Finnish bioeconomy strategy. Finland possesses a high level of expertise and industrial capability that allows us to export knowledge and technical solutions to other countries. Enhancement of well-being and social developments are important elements in this strategy [51]. The Sustainable Bioenergy Solutions for Tomorrow (BEST) programme 
was developed as a platform for enhancing existing innovative solutions and knowledge, and finding answers to critical questions raised by stakeholders in the bioenergy operations environment, including issues of the social sustainability of companies and their suppliers. The BEST programme was considered pre-commercial research and involved collaborations between industry and academia. The programme ran from 2013 to 2016 and involved a number of stakeholder workshops and knowledge exchange events. Analysis and selection of social sustainability criteria and social risks identification that fit bioenergy value chains was one of main objectives of the project [52].

During BEST programme implementation, companies involved in the programme were exploring new markets for their bioenergy businesses. Studies have been done to analyse supply chain risks, such as security of supply, infrastructure gaps, and lack of a favourable political framework. Two of the new markets explored demonstrated social sustainability challenges. One of the potential markets for bioenergy development was India. During the first phase of BEST programme implementation, an assessment was done to survey the attitudes toward bioenergy and assess the willingness of Indian farmers to supply surplus biomass to an envisioned biomass-based power plant. The results indicated that Indian farmers are willing to sell biomass to energy and perceive such bioenergy as positive socioeconomic development, having a potential for a positive environmental impact for the region [53]. However, biomass resource assessment showed that waste management practices and cultural specifics had limited implementation potential. Moreover, it was concluded that there was a need for new state policies and regulations for the biomass market's development, in order to avoid price fluctuations that may harm the economics of planned biomass-based power plants [53,54].

During the second phase of BEST programme implementation, South and Central Poland farmers' willingness to supply biomass for bioenergy generation was evaluated. The results showed a different picture from that of India. Based on data collected from 210 farmers, it was indicated that the majority of Polish farmers in both regions were unwilling to collect, store, and transport biomass to even the nearest energy production plants [55]. As well, the biomass price formation did not encourage Polish farmers to get involved in the bioenergy supply chain. Even though they there were no infrastructural or political obstacles, the unwillingness to supply biomass left no chance for a market to be developed [52,53].

In consequence, both markets were acknowledged as unsuitable for potential bioenergy development, despite the fact that research indicated that many socioeconomic benefits could have been gained in both cases.

However, there is also empirical evidence of global companies managing to overcome social sustainability challenges and that their operation on the new market resulted in positive social and economic benefits for both the company and the country of resource origin.

The Story of Veracel Mill development in Brazil (owned by Stora Enso) showed that it is possible to create high positive impact in the Bahía region through employment, paying taxes, supporting the education and livelihood in local communities, and protecting natural resources and restoring rainforests. This was due to many years of constructive, open dialogue that enhanced cooperation with the local communities.

Nevertheless, as most large companies with multinational supply chains and raw material sourcing in less developed countries, Veracel Mill had to deal with and overcome many challenges related to social sustainability issues. The recent issue of land-use conflicts showed that the company had to perform an open dialog with local communities and public in order to resolve the conflict, keep its positive image, and be able to find solution that ultimately benefited both sides [56].

Encouraging community-based benefits and presenting positive perspectives for local communities should be seen as an important element of social sustainability strategies for the company. Companies must ensure that the production of raw materials, as well as labour practices, remain sustainable, and local communities involved in the production of raw materials are treated fairly and could prosper not just economically, but also socially. Moreover, expanding the producer's influence beyond local boundaries helps create a positive image for the company at the global level [57]. 
Large enterprises like Pindorama Mill that operate upstream of bioethanol supply chain production in Brazil are setting up goals to reach social inclusion via providing education, occupational training, improving professional capacity, creating new employment opportunities, and enhancing income growth for local communities [58].

On the other hand, the length and complexity of bioenergy production supply chains create situations in which the social sustainability of local communities gets put under pressure. A number of case studies documented that biomass sourcing in developing countries for bioenergy production carries much higher social risks than in the developed countries, due to the absence of a regulatory framework and non-compliance with social rules and regulations $[59,60]$.

Successful companies have to go beyond their usual practices and create new programs that will insure well-being of local communities. For example, of Finnish company Neste demonstrated that by creating the "Neste Human Rights Commitment" program, they were are able to detect, monitor, and correct occurring problems related to human rights bridge [61].

An Ethiopian case of water use conflict indicated the importance of government involvement. In order to attract foreign investment, the Ethiopian government was giving guaranties of water access to companies coming to the region. This, however, created a scarcity or lack of access to water for local communities. By using the nexus approach, the conflict was solved companies were motivated to make investments into the Ethiopian economy. Communication between regions and companies played crucial role in solving the water-use conflict [62].

Table 2 summarizes these case studies, their background, their solutions, and the impact of the solutions in terms of social value creation.

The evidence from Table 2 indicates that despite numerous challenges companies faced in new markets, it is possible to create positive social values in a long-run. Depending on market specifics and obstacle location in the supply chain, companies built different communication approaches in order to overcome or and manage appeared conflicts. The biggest obstacle that led to market abundance was inability to influence or change local or national policies. High financial risks also have been a strong factor for "no go" decision. However, other examples showed that companies can do well if they are able to build proper communication with national governments.

Our findings demonstrate that companies were able not just to overcome social sustainability risks and conflicts, but they also created new approaches to handling uprising issues, bringing social benefits to local communities, and enhancing the overall sustainability of the region they operated in. Adaptation of best social sustainability practices as well as transfer of knowledge and technologies allowed those companies to succeed and continue operations for many years.

GRI G4 recommends companies mapping all potential social or economic impacts of their operations, regardless whether they happen within or outside of the organizations [18]. Using the GRI approach, Figure 1 illustrates where within these boundary settings the seven empirical cases are located. As can be seen in the Figure 1, most of the issues happened upstream, and outside of the organizational boundary.

The GRI guidelines suggest that companies need to list all issues also outside of the organizations where impacts related to social sustainability can happen, in order to demonstrate that they are aware of these impacts in their value chains. While this is a useful approach, what is missing from this picture is the level of control or influence the companies can have on these external issues. Stakeholder engagement can ensure broad support and buy-in for decisions on bioenergy at both a project and a policy levels. It ensures that stakeholders are informed of the developments, which is a first step to gaining support for the policy or project and its later implementation. It does this by allowing stakeholder differences to be addressed through dialogue, and for conflicts to be managed on time. Stakeholder engagement can also help government with compliance. Where stakeholders are involved in monitoring activities, they can help notify authorities if unanticipated consequences arise that require adaptive management processes [63]. 
Table 2. Empirical evidence from companies.

\begin{tabular}{|c|c|c|c|c|c|c|}
\hline$\#$ & Empirical Case & Supply Chain Obstacle & Background/Reason & Evidences to Find Solution & Potential Benefit/Social Value Creation & Source \\
\hline 1 & $\begin{array}{l}\text { BEST Project India } \\
\text { Market }\end{array}$ & Infrastructure & $\begin{array}{l}\text { Concern about the } \\
\text { continuity of supply, } \\
\text { supply chains are not } \\
\text { developed properly }\end{array}$ & Follow-up and reconsider market late & $\begin{array}{l}\text { Industrialization, potential use of } \\
\text { unused raw material, jobs, } \\
\text { infrastructural improvements ... }\end{array}$ & BEST 2015, Final Report [52] \\
\hline 2 & & Policy & $\begin{array}{l}\text { Lack of stability, state } \\
\text { policies undeveloped }\end{array}$ & $\begin{array}{l}\text { Follow-up political situation and } \\
\text { reconsider market late }\end{array}$ & Social standards development & BEST 2015, Final Report [52] \\
\hline 3 & $\begin{array}{c}\text { Stora Enso } \\
\text { Brazil Veracel Mill }\end{array}$ & Land-use conflict & $\begin{array}{l}\text { Landless movement, illegal } \\
\text { occupancy }\end{array}$ & $\begin{array}{l}\text { Invested a lot into conflicts resolution, } \\
\text { open discussion with public }\end{array}$ & $\begin{array}{c}\text { Reforestations of depressed areas } \\
\text { (environmental) } \\
\text { New jobs } \\
\text { Local communities involvement }\end{array}$ & Stora Enso, 2019 [56] \\
\hline 4 & $\begin{array}{l}\text { Pindorama Mill, } \\
\text { Brazil }\end{array}$ & $\begin{array}{l}\text { Occupational Health and } \\
\text { Safety } \\
\text { Absence of Training }\end{array}$ & $\begin{array}{l}\text { Poor infrastructure } \\
\text { Production sites not } \\
\text { established properly. }\end{array}$ & $\begin{array}{l}\text { Provided with individual protection } \\
\text { equipment and life insurance for all } \\
\text { the workers } \\
\text { Creating Cooperatives } \\
\text { CETRUP }\end{array}$ & $\begin{array}{l}\text { Decent and safe jobs for workers } \\
\text { (socioeconomic) } \\
\text { Educational programs } \\
\text { Local communities involvement }\end{array}$ & Rutz, 2014 [58] \\
\hline 5 & $\begin{array}{l}\text { BEST Project } \\
\text { Polish Market }\end{array}$ & $\begin{array}{l}\text { Raw material price, no state } \\
\text { subsidiaries }\end{array}$ & $\begin{array}{l}\text { Farmers' unwillingness to } \\
\text { supply biomass since more } \\
\text { profit are gained from } \\
\text { higher value crops }\end{array}$ & $\begin{array}{l}\text { Follow-up, consider other } \\
\text { opportunities }\end{array}$ & $\begin{array}{c}\text { Diversification of energy supply } \\
\text { Energy Security } \\
\text { New jobs }\end{array}$ & BEST 2015, Final Report [52] \\
\hline 6 & Neste & Human rights & $\begin{array}{l}\text { Reports of human rights } \\
\text { violation in palm oil } \\
\text { plantation }\end{array}$ & $\begin{array}{l}\text { Neste Human Rights Commitment } \\
\text { Programs were developed, constant } \\
\text { monitoring }\end{array}$ & $\begin{array}{l}\text { Safety and quality of life improvements } \\
\text { for local communities }\end{array}$ & Neste, 2017 [61]. \\
\hline 7 & Sugarcane Ethiopia & Water use conflict & $\begin{array}{l}\text { Sugarcane plantations' use } \\
\text { of water }\end{array}$ & Nexus approach used to solve conflict & $\begin{array}{l}\text { Well-being enhancement via water } \\
\text { supply improvements }\end{array}$ & Hailemariam, 2019 [62] \\
\hline
\end{tabular}




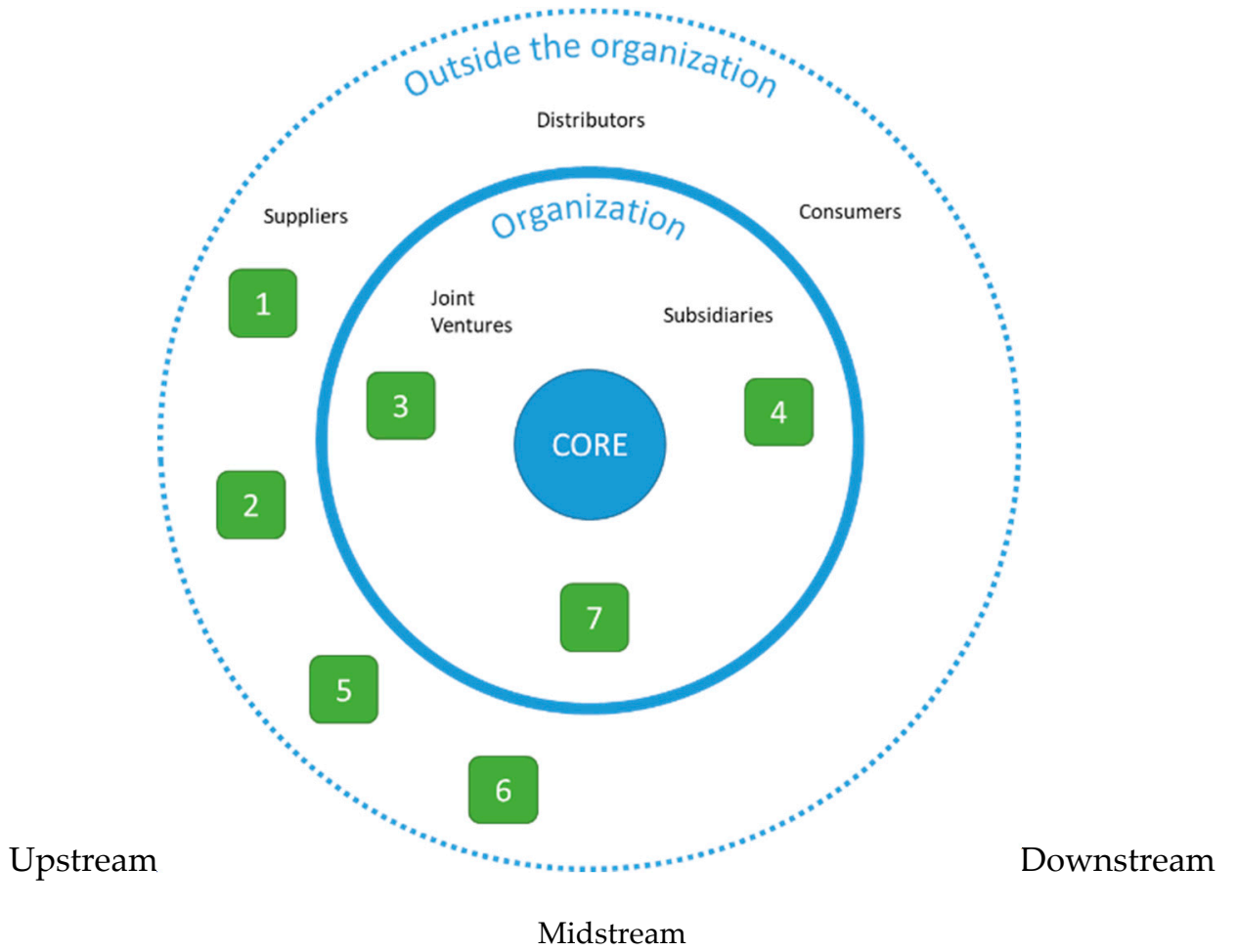

Figure 1. Empirical cases' locations within boundary settings.
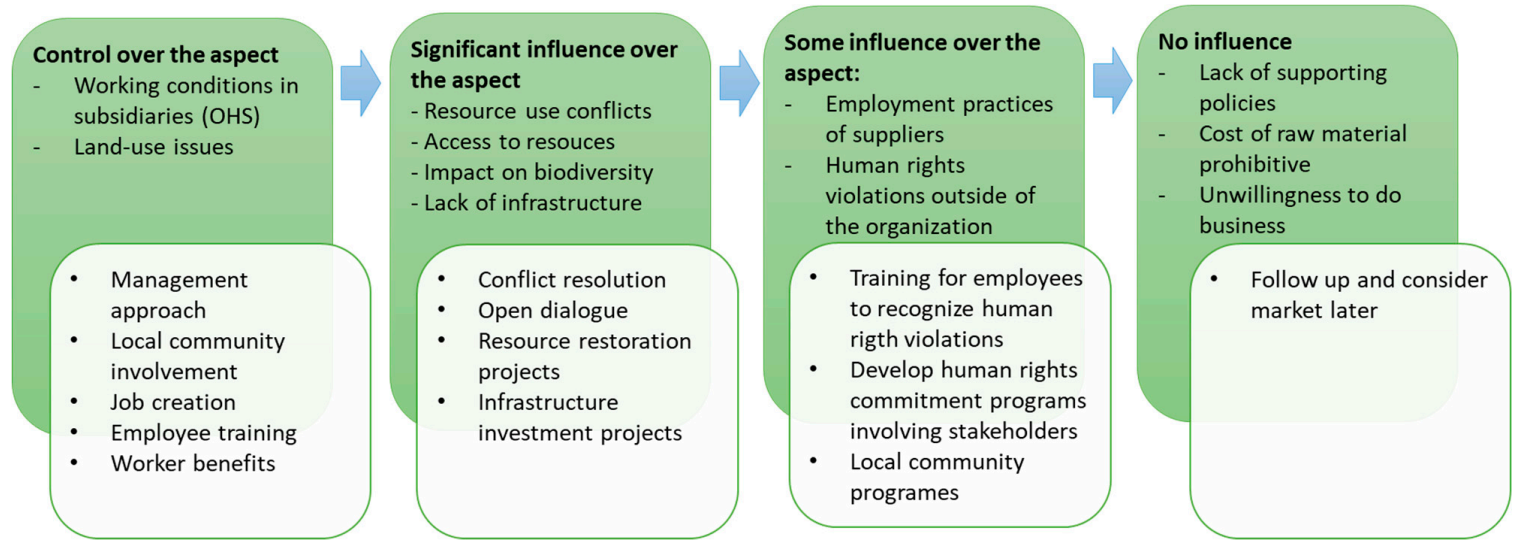

Figure 2. Social risks decision-making flow chart.

Based on these evidences and considerations, we present the social risks decision-making flow chart in Figure 2. The main suggestion is that companies prioritize and select action based on their level of influence on the issue. The examples presented in the chart originate from the case studies reviewed and summarized in Table 2. It is structured with respect to the recognition that control over the social sustainability issue is strongly correlated with the ability to affect outcomes.

In the top row, Figure 2 illustrates the level of company's control over potential social risks, while the actions are listed in the bottom row. In case the company has control over the issue, it needs to choose what actions should be taken. If there is no control over the issue but there is the power to influence it, the company needs to make a strategic decision on how to affect the influence. If the power to influence is minor, it is a potential risk and a cause for concern. In the case, however, wherein the company has no impact on the issue, a no-go decision could be wise; however, the company can monitor the market and follow-up. For example, in case 2, later, the opportunity presented itself to enter the Indian market but with another technical solution—solar energy in this case. 
Even if there is no direct impact on business, companies need to consider social sustainability issues that can harm the company's reputation. Should the company have control over the issue, a decision needs to be made on what actions to take and how to communicate it to stakeholders. If there is a significant control over the issue, the options to influence need to be considered, the action to be taken decided upon, and the decision communicated to stakeholders. However, if the company has no control over an issue that may negative affect its image, firstly, the risk needs to be assessed; secondly, a decision needs to be made how to communicate the issue. However, if there is no way for a company to influence a subject of social sustainability that can damage its image, the company will need to consider the potential risk and formulate response strategies. Key in all cases is open dialog with stakeholders, since transparency is of foremost importance in social sustainability related issues.

\section{Advanced Social Sustainability Supply Chain Practices}

GRI standards are encouraging the use of sustainability reporting to internal and external stakeholders as good practice of measuring, disclosing, and being accountable for organizational performance towards the goal of sustainable development. Sustainability reporting is a broad term considered synonymous with others used to describe reporting on economic, environmental, and social impacts. Social sustainability report should provide a balanced and reasonable representation of the sustainability performance of a reporting organization-including both positive and negative contributions and risks.

As it was mentioned earlier, most companies do report on basic social issues, ones they have to report by law. However, GRI guidelines give a much wider prospective on how to evaluate a company's social sustainability state. It gives many options and details on all basic social risks and even more hints on advanced social risks. Table 3 lists the disclosures recommended by GRI, for companies committed to monitor basic and advanced social sustainability risk, both internal and external.

Table 3. Basic versus advanced social-risks-based GRI guidelines' recommendations.

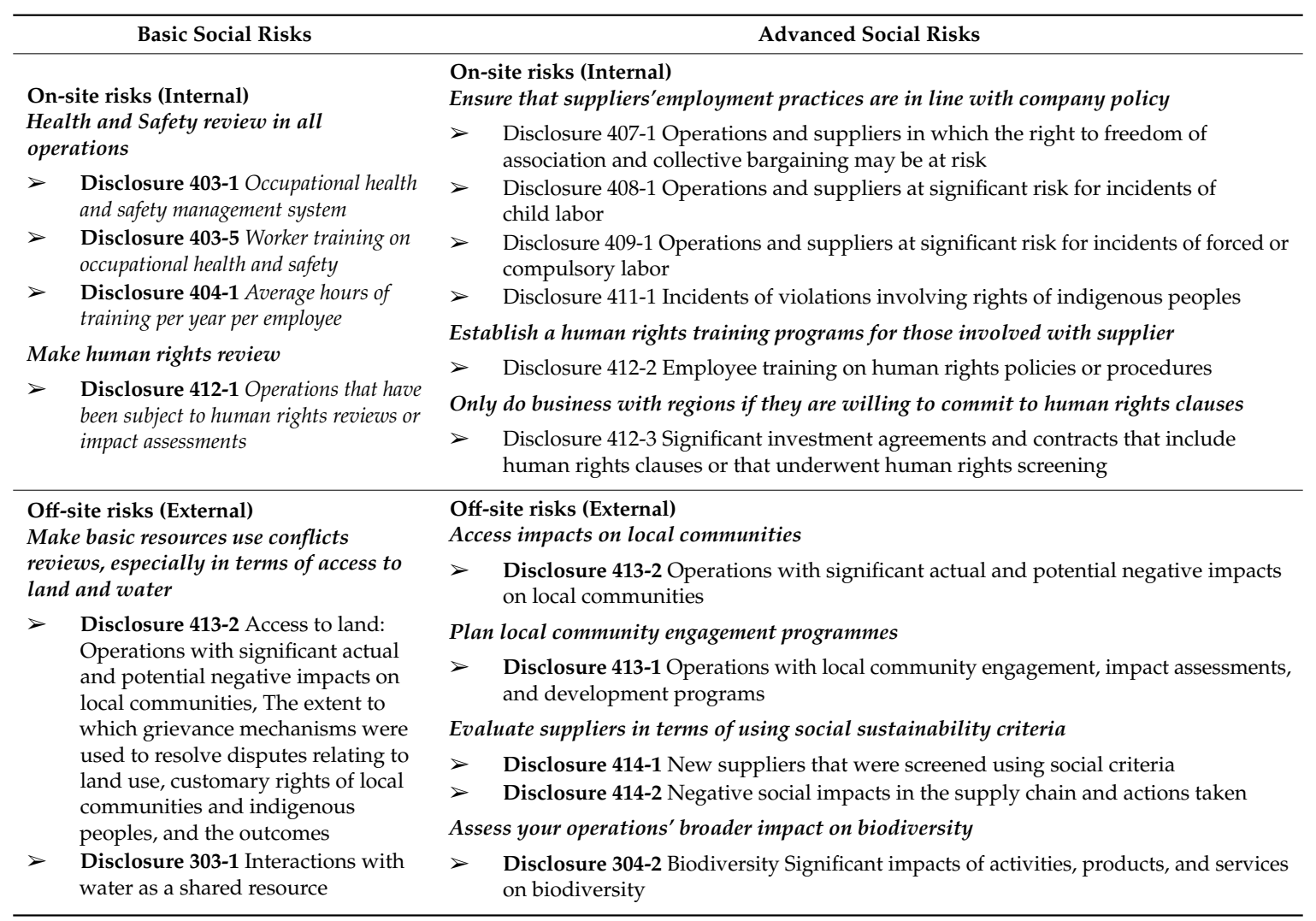




\section{Discussion and Conclusions}

The main question of our research was, "How can bioenergy production companies manage the social sustainability risks in their supply chain/country of raw material origin." While assessing new markets, potential companies have to evaluate all possible economic scenarios and social risks as well as take into account various environmental factors and political perspectives that may create obstacles for successful production. However, very often, the main criteria for such assessments are related directly to financial gain and very little to potential social values that can be created in the countries of raw materials origin.

The decision of new market entry can be based on a well-designed approach that takes into account multiple scenarios, perspectives, and specific social criteria, and can be tailored for each specific case. Social risks can be selected on a different basis. It could be: local community relevance, economic practicality, reliability, importance, simplicity, and others. New G4 guidelines provide guidelines for locating and managing different aspects of sustainability, either material or not along organizational value chains.

Governance can become one of the most important decision-making factors for companies to enter new markets. Often social risks are dependent on national and regional contexts. That is why the importance of communication between national/regional government and bioenergy production companies should be stressed more. Additionally, well-structured governing strategies may not only reduce social sustainability risks in the supply chain, but also enhance interconnections between all three sustainability dimensions. Moreover, social risks should be presented in simple and understandable terms for stakeholders

The cases we have studied demonstrated a wide range of decision-making methods for whether the company wants to deal and communicate challenging issues on new markets or just escape it by not going. The challenge for bioenergy production companies is how to manage wide range of advanced social risks they may face upstream of their production lines. The approach of "going above and beyond" basic standards allows developing an effective set of social sustainability supply chain practices. Social commitments made to the local communities by the companies together with local government can dramatically improve state of well- being in production regions [64].

Looking on empirical data, we can see that that both basic and advanced social sustainability supply chain practices are connected to the level of stakeholder involvement and to a company's openness and desire to build and demonstrate positive social sustainability culture to the public. GRI suggests that sector specific indicators can be used for reporting, if necessary. They will reveal unique market characteristics and connect to specific types of industrial actives in the supply chains. Reporting with respect to GRI social indicators will help capturing the interests and concerns of relevant stakeholders in the bioenergy sector.

Bioenergy production companies with socially sustainable supply chain practices and open mind-sets are more likely to detect and manage advanced social risks and bring positive social impacts inside and outside of the upstream areas of their supply chains [65].

It appears that companies, which adopt sustainability standards and practices reporting a wide range of advanced indicators, may achieve a social sustainability state, and at the same time demonstrate profitable financial capabilities. In addition, the GRI boundary setting approach helps companies to define impacts that may potentially occur along bioenergy production supply chains.

Well-tailored, but flexible, socially sustainable supply chain practices have become a key in decision-making processes when entering new markets. By paying attention to people's and communities' needs within and outside of the organization along the supply chain, bioenergy companies can reduce replacement costs and avoid unexpected risks and supply chain disruptions related to communities' resistance and natural resources use issues.

Our research showed the importance of good social sustainability practices implementation and establishment of an effective communication between bioenergy production companies and national/regional stakeholders. We have determined that open dialog may reduce social risks and 
improve social well-being of local communities in the upstream of bioenergy production supply chain. The approach "going above and beyond" basic standards while applying socially sustainable management actions allows companies develop their own unique set of efficient social sustainability supply chain practices and create positive benefits for all players involved into bioenergy production supply chain.

European renewable energy policies and targets push multi-national bioenergy production companies to explore new markets [1]. However, the directives are limited in terms of guidelines of social sustainability practices. Social or economic obstacles as well as non-standard situations that multi-national companies have to face when entering developing markets are often holding them back. Fear of reputation loss, potential consumer boycotts due to the market's social development specifics (labour rights, land use conflicts, water access standards, etc.), or high financial risks, drive companies to abandon markets. However, our research findings indicate that market avoidance is not always the best solution and can be considered a "lost opportunity risk". Companies that were able to adapt best practices and transfer technological knowledge demonstrated high opportunities for developing new trends, through developing socially sustainable global supply chains.

Although research on socially sustainable bioenergy production supply chains and assessment tools have emerged in recent years, there is still room for improvement and further research to be implemented. New tools, frameworks, and guidelines have to be developed in order to enhance and maintain the social sustainability of global bioenergy production supply chains. The limitation of our study was the sample size available for evaluation; however, new players entering the bioenergy sector will provide us with diversified data, and we can extend our research to demonstrate the importance of social sustainability practices in global supply chains. We believe that social stability in countries with bioenergy resource production and the diversity of potential markets create opportunities for the bioenergy sector, improve global access to modern energy services, and aid in reaching climate and energy targets.

Author Contributions: Conceptualization E.F. and E.P.; methodology, E.F., K.A. and E.P.; investigation, E.F., K.A. and E.P.; resources, E.F., K.A. and E.P.; writing-original draft preparation, E.F.; writing-review and editing, E.F., K.A. and E.P.; visualization, E.F. and E.P.; supervision, K.A. and E.P. All authors have read and agreed to the published version of the manuscript.

Funding: This research was funded by UniOGS.

Conflicts of Interest: The authors declare no conflict of interest.

\section{References}

1. RED II Directive (EU) 2018 of the European Parliament and of the Council of 11 December 2018 on the Promotion of the Use of Energy from Renewable Sources. Available online: https:/eur-lex.europa.eu/eli/dir/ 2018/2001/oj (accessed on 5 December 2019).

2. EC, Europa. Renewable Energy Directive. 2018. Available online: https://ec.europa.eu/energy/en/topics/ renewable-energy/renewable-energy-directive/overview (accessed on 5 December 2019).

3. EC, Europa. Assessing the Impact of Biofuels Production on Developing Countries from the Point of View of Policy Coherence for Development, Final Report. 2013. Available online: https://ec.europa.eu/europeaid/sites/devco/files/study-impact-assesment-biofuelsproduction-on-development-pcd-201302_en_2.pdf (accessed on 10 November 2019).

4. UN. United Nations Global Impact, Reports. 2019. Available online: https://www.unglobalcompact.org/ (accessed on 7 December 2019).

5. DEBEG. Developing Bioenergy Governance Portal, Bioenergy Conflicts Database. 2019. Available online: http://www.debeg.org/en/bioenergy_conflicts_database/?PHPSESSID=f7814e70fbcba1a2625487026f1aeca3 (accessed on 10 January 2020).

6. Kaplan, R.; Mikes, A. Managing Risks: A New Framework, Harvard Business Review. 2012. Available online: https://hbr.org/2012/06/managing-risks-a-new-framework (accessed on 7 December 2019). 
7. Hofmann, H.; Busse, C.; Bode, C.; Henke, M. Sustainability-Related Supply Chain Risks: Conceptualization and Management. Bus. Strategy Environ. 2014, 23, 160-172. [CrossRef]

8. Xu, M.; Cui, Y.; Hu, M.; Xu, X.; Zhang, Z.; Liang, S.; Qu, S. Supply chain sustainability risk and assessment. J. Clean. Prod. 2019, 225, 857-867. [CrossRef]

9. Tseng, M.; Islam, S.; Karia, N.; Fauzi, F.; Afrin, S. A literature review on green supply chain management: Trends and future challenges. Resour. Conserv. Recycl. 2019, 141, 145-162. [CrossRef]

10. Govindan, K.; Rajendran, S.; Sarkis, J.; Murugesan, P. Multi criteria decision making approaches for green supplier evaluation and selection: A literature review. J. Clean. Prod. 2015, 98, 66-83. [CrossRef]

11. Roehrich, J.; Hoejmose, S.; Overland, V. Driving green supply chain management performance through supplier selection and value internalisation: A self-determination theory perspective. Int. J. Oper. Prod. Manage. 2017, 37, 489-509. [CrossRef]

12. Hollos, D.; Blome, C.; Foerstl, K. Does sustainable supplier co-operation affect performance? Examining implications for the triple bottom line. Int. J. Prod. Res. 2012, 50, 2968-2986. [CrossRef]

13. Yawar, S.; Seuring, S. The role of supplier development in managing social and societal issues in supply chains. J. Clean. Prod. 2018, 182, 227-237. [CrossRef]

14. Mani, V.; Gunasekaran, A.; Delgado, C. Enhancing supply chain performance through supplier social sustainability: An emerging economy perspective. Int. J. Prod. Econ. 2018, 195, 259-272. [CrossRef]

15. Giannakis, M.; Papadopoulos, T. Supply chain sustainability: A risk management approach. Int. J. Prod. Econ. 2016, 171, 455-470. [CrossRef]

16. Esteves, A.; Vanclay, F. Social impact assessment: The state of the art. Impact Assess. Proj. Apprais. 2012, 30, 34-42. [CrossRef]

17. EC, Europa, EU, Non-Financial Reporting. 2018. Available online: https://ec.europa.eu/info/businesseconomy-euro/company-reporting-and-auditing/company-reporting/non-financial-reporting_en (accessed on 15 December 2019).

18. Global Reporting Initiative (GRI). 2017. Available online: https:/www.globalreporting.org/information/ news-and-press-center/newsarchive/Pages/2017.aspx (accessed on 15 December 2019).

19. Quarshie, A.M.; Salmi, A.; Leuschner, R. Sustainability and corporate social responsibility in supply chains: The state of research in supply chain management and business ethics journals. J. Purch. Supply Manag. 2016, 22, 82-97. [CrossRef]

20. Hoejmose, S.; Roehrich, J.; Grosvold, J. Is doing more doing better? The relationship between responsible supply chain management and corporate reputation. Ind. Mark. Manag. 2014, 43, 77-90. [CrossRef]

21. Wang, Z.; Osseweijer, P.; Duque, J.P. Assessing Social Sustainability for Biofuel Supply Chains: The Case of Aviation Biofuel in Brazil. In Proceedings of the 2017 IEEE Conference on Technologies for Sustainability (SusTech), Phoenix, AZ, USA, 12-14 November 2017; pp. 1-5. [CrossRef]

22. Tajbakhsh, A.; Hassini, E. A data envelopment analysis approach to evaluate sustainability in supply chain networks. J. Clean. Prod. 2015, 105, 74-85. [CrossRef]

23. Wu, T.; Blackhurst, J. Managing Supply Chain Risk and Vulnerability: Tools and Methods for Supply Chain Decision Makers; Springer: Berlin/Heidelberg, Germany, 2009.

24. Marshall, D.; McCarthy, L.; McGrath, P.; Claudy, M. Going above and beyond: How sustainability culture and entrepreneurial orientation drive social sustainability supply chain practice adoption. Supply Chain Manag. Int. J. 2015, 20, 434-454. [CrossRef]

25. Foerstl, K.; Reuter, C.; Hartmann, E.; Blome, C. Managing supplier sustainability risks in a dynamically changing environment-Sustainable supplier management in the chemical industry. J. Purch. Supply Manag. 2010, 16, 118-130. [CrossRef]

26. Al-Sheyadi, A.; Muyldermans, L.; Kauppi, K. The complementarity of green supply chain management practices and the impact on environmental performance. J. Environ. Manag. 2019, 242, 186-198. [CrossRef]

27. Yue, D.; You, F.; Snyder, W. Biomass-to-bioenergy and biofuel supply chain optimization: Overview, key issues and challenges. Comput. Chem. Eng. 2014, 66, 36-56. [CrossRef]

28. Oliveira, U.; Marins, F.; Rocha, H.; Salomon, V. The ISO 31000 standard in supply chain risk management. J. Clean. Prod. 2017, 151, 616-633. [CrossRef]

29. Revilla, E.; Saenz, M.J. The impact of risk management on the frequency of supply chain disruptions: A configurational approach. Int. J. Oper. Prod. Manag. 2017, 37, 557-576. [CrossRef] 
30. Brusset, X.; Teller, C. Supply chain capabilities, risks, and resilience. Int. J. Prod. Econ. 2017, 184, $59-68$. [CrossRef]

31. Zimon, D.; Madzík, P. Standardized management systems and risk management in the supply chain. Int. J. Q. Reliab. Manag. 2019, 37, 305-327. [CrossRef]

32. Gu, Z.; Zhang, S. Endogenous default risk in supply chain and non-linear pricing. Int. J. Prod. Econ. 2012, 139, 90-96. [CrossRef]

33. Porter, M.E.; Kramer, M.R. Strategy \& Society: The Link between Competitive Advantage and Corporate Social Responsibility. Harv. Bus. Rev. 2006, 84, 78-85.

34. Das, K.; Lashkari, R.S. Risk readiness and resiliency planning for a supply chain. Int. J. Prod. Res. 2015, 53, 6752-6771. [CrossRef]

35. Gold, S.; Schleper, M. A pathway towards true sustainability: A recognition foundation of sustainable supply chain management. Eur. Manag. J. 2017, 35, 425-429. [CrossRef]

36. Benites-Lazaro, L.L.; Giatti, L.; Giarolla, A. Sustainability and governance of sugarcane ethanol companies in Brazil: Topic modeling analysis of CSR reporting. J. Clean. Prod. 2018, 197, 583-591. [CrossRef]

37. Dai, J.; Blackhurst, J. A four-phase AHP-QFD approach for supplier assessment: A sustainability perspective. Int. J. Prod. Res. 2012, 50, 5474-5490. [CrossRef]

38. Pehlken, A.; Madena, K.; Aden, C.; Klenke, T. Forming stakeholder alliances to unlock alternative and unused biomass potentials in bioenergy regions. J. Clean. Prod. 2016, 110, 66-77. [CrossRef]

39. Röder, M. More than food or fuel. Stakeholder perceptions of anaerobic digestion and land use; a case study from the United Kingdom. Energy Policy 2016, 97, 73-81.

40. Chanthawong, A.; Dhakal, S. Stakeholders' perceptions on challenges and opportunities for biodiesel and bioethanol policy development in Thailand. Energy Policy 2016, 91, 189-206. [CrossRef]

41. Miret, C.; Chazara, P.; Montastruc, L.; Negny, S.; Domenech, S. Design of bioethanol green supply chain: Comparison between first and second generation biomass concerning economic, environmental and social criteria. Comput. Chem. Eng. 2016, 85, 16-35. [CrossRef]

42. Upham, P.; Riesch, H.; Tomei, J.; Thornley, P. The sustainability of forestry biomass supply for EU bioenergy: A post-normal approach to environmental risk and uncertainty. Environ. Sci. Policy 2011, 14, 510-518. [CrossRef]

43. Nakamba, C.; Chan, P.; Sharmina, M. How does social sustainability feature in studies of supply chain management? A review and research agenda. Supply Chain Manag. 2017, 22, 522-541. [CrossRef]

44. Walker, H.; Seuring, S.; Sarkis, J.; Klassen, R. Sustainable operations management: Recent trends and future directions. Int. J. Oper. Prod. Manag. 2014, 34. [CrossRef]

45. Amann, M.; KRoehrich, J.; Eßig, M.; Harland, C. Driving sustainable supply chain management in the public sector: The importance of public procurement in the EU. Supply Chain Manag. Int. J. 2014, 19, 351-366. [CrossRef]

46. Klassen, R.D.; Vereecke, A. Social issues in supply chains: Capabilities link responsibility, risk (opportunity), and performance. Int. J. Prod. Econ. 2012, 140, 103-115. [CrossRef]

47. Thorlakson, T.; de Zegher, J.F.; Lambin, E.F. Companies' contribution to sustainability through global supply chains. Proc. Natl. Acad. Sci. USA 2018, 115, 2072-2077. [CrossRef]

48. Winter, M.; Knemeyer, A.M. Exploring the integration of sustainability and supply chain management: Current state and opportunities for future inquiry. Int. J. Phys. Distrib. Logist. Manag. 2013, 43, 18-38. [CrossRef]

49. Grosvold, J.U.; Hoejmose, S.K.; Roehrich, J. Squaring the circle: Management, measurement and performance of sustainability in supply chains. Supply Chain Manag. Int. J. 2014, 19, 292-305. [CrossRef]

50. McCarthy, L. Impact of Social Sustainability Orientation and Supply Chain Practices on Operational Performance. Int. J. Oper. Prod. Manag. 2018, 38, 2344-2366. [CrossRef]

51. LUKE. Finnish Bioeconomy in Numbers. 2017. Available online: https://www.luke.fi/en/natural-resources/ finnish-bioeconomy-in-numbers/ (accessed on 5 December 2019).

52. BEST. Final Report. 2015. Available online: http://bestfinalreport.fi/content/new-markets (accessed on 7 January 2020).

53. Zyadin, A.; Natarajan, K.; Chauhan, S.; Singh, H.; Hassan, M.K.; Pappinen, A.; Pelkonen, P. Indian Farmers' Perceptions and Willingness to Supply Surplus Biomass to an Envisioned Biomass-Based Power Plant. Challenges 2015, 6, 42-54. [CrossRef] 
54. Natarajan, K.; Latva-Käyrä, P.; Zyadin, A.; Chauhan, S.; Singh, H.; Pappinen, A.; Pelkonen, P. Biomass Resource Assessment and Existing Biomass Use in the Madhya Pradesh, Maharashtra, and Tamil Nadu States of India. Challenges 2015, 6, 158-172. [CrossRef]

55. Zyadin, A.; Natarajan, K.; Igliński, B.; Iglińska, A.; Kaczmarek, A.; Kajdanek, J.; Pelkonen, P. Farmers' willingness to supply biomass for energy generation: Evidence from South and Central Poland. Biofuels 2017, 8, 421-430. [CrossRef]

56. Stora Enso. Stora Enso's Response. 2019. Available online: https://www.storaenso.com/en/sustainability/ latest-updates-and-stories/veracel-in-yle-television-programme-spotlight (accessed on 7 January 2020).

57. Gadema, Z.; Oglethorpe, D. The use and usefulness of carbon labelling food: A policy perspective from a survey of UK supermarket shoppers. Food Policy 2011, 36, 815-822. [CrossRef]

58. Rutz, D.; Janssen, R. Socio-Economic Impacts of Bioenergy Production; Springer: Berlin/Heidelberg, Germany, 2014.

59. Persson, U.M. The impact of biofuel demand on agricultural commodity prices: A systematic review. Wiley Interdiscip. Rev. Energy Environ. 2014, 4, 410-428. [CrossRef]

60. Smith, P.; Bustamante, M.; Ahammad, H.; Clark, H.; Dong, H.; Elsiddig, E.A.; Masera, O. Agriculture, Forestry and Other Land Use (AFOLU). In Climate Change 2014: Mitigation of Climate Change; Contribution of Working Group III to the Fifth Assessment Report of the Intergovernmental Panel on Climate Change; Cambridge University Press: New York, NY, USA, 2014.

61. Neste Human Rights Commitment. 2017. Available online: https:/www.neste.com/sites/neste. com/files/attachments/corporate/sustainability/managing_sustainability/nhrc_17oct2017.pdf (accessed on 10 December 2019).

62. Hailemariam, W.; Silalertruksa, T. Water-Energy—Food Nexus of Sugarcane Production in Ethiopia. Environ. Eng. Sci. 2019, 36, 118-130.

63. UNEP. Stakeholder Engagement Handbook. 2018. Available online: https://www.unenvironment.org/ resources/publication/stakeholder-engagement-handbook (accessed on 5 December 2019).

64. Lähtinen, K.; Myllyviita, T.; Leskinen, P.; Pitkänen, S.K. A systematic literature review on indicators to assess local sustainability of forest energy production. Renew. Sustain. Energy Rev. 2015, 40, 1202-1216. [CrossRef]

65. Mahendra, R.; Avinash, P.I. Sustainable Bioenergy. 2019. Available online: https://www.sciencedirect.com/ book/9780128176542/sustainable-bioenergy\#book-info (accessed on 7 January 2020).

(C) 2020 by the authors. Licensee MDPI, Basel, Switzerland. This article is an open access article distributed under the terms and conditions of the Creative Commons Attribution (CC BY) license (http://creativecommons.org/licenses/by/4.0/). 